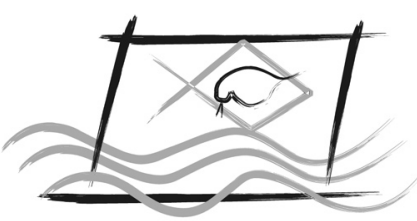

J. Braz. Soc. Ecotoxicol., v. 7, n. 1, 2012, 1-7

doi: $10.5132 / j b s e .2012 .01 .001$

ECOTOX - BRASIL

\title{
Micronucleus formation induced by biomass burning particles derived from biomass burning induce high micronucleus frequency in Tradescantia pallida assay (TRAD-MN)
}

\author{
I.C. Silva ${ }^{1 \#}$, M.C.C. Peron ${ }^{1 \#}$, M.A. ArbeX 4 , A.J.F.C. Lichtenfels ${ }^{2}$, D.J.A. Lobo², M.P. Giocondo ${ }^{1}$, \\ M. Macchione ${ }^{2}$, M. SAIKI ${ }^{3}$, P.H.N. SAldiva ${ }^{2} \&$ C.P. SoAres ${ }^{1 *}$ \\ ${ }^{1}$ Laboratory of Clinical Cytology, Department of Clinical Analysis, School of Pharmaceutical Sciences, UNESP, \\ São Paulo State University. R. Expedicionários do Brasil, 1621, CEP 14801 902, Araraquara, São Paulo, Brazil. \\ ${ }^{2}$ Laboratory of Experimental Air pollution, Faculty of Medicine, Department of Pathology, School of Medicine, \\ University of São Paulo (USP), Av. Dr Arnaldo, 455, SP, CEP 01246-903, São Paulo, Brazil. \\ ${ }^{3}$ Neutron Activation Analysis Laboratory, Av. Professor Lineu Prestes 2242, CEP 05508-000, São Paulo, SP, Brazil. \\ ${ }^{4}$ Department of Medicine, School Paulista of Medicine, UNIFESP, University Federal of São Paulo, \\ Rua Botucatu 740, 04023-062, São Paulo, Brazil. \\ ${ }^{\#}$ Both authors contributed equally to this work
}

(Received June 05, 2008; Accept December 30, 2010)

\begin{abstract}
Manual harvesting is usually done after to sugar cane burning which is responsible for seasonal emission of air pollutants in Brazil and it is believed to be responsible for deleterious health effects in exposed populations. The mutagenic potential of sugar cane burning harvesting particulate and particle surrogates of residual oil fly ash (ROFA) were evaluated in assays measuring micronuclei (MN) in the pollen mother cells of Tradescantia pallida (TRAD-MN). Micronuclei frequencies in TRAD-MN to sugar cane burning residues (SCBR) at doses 0.3 and $0.03 \mathrm{mg} / \mathrm{mL}$ were respectively $2.18 \pm 0.35$ and $5.53 \pm 1.04$, whereas to ROFA from incinerator and ROFA from an electrostatic precipitator installed in one of the chimneys of a steel plant, MN frequencies were, respectively, $3.43 \pm 0.7$ and $4.90 \pm 1.07$. Significant differences were detected among the groups $(\mathrm{p}<0.001)$, demonstrating that SCBR was at least as genotoxic as the fossil fuel derived particles. The results suggest that the burning process to harvest sugar cane should be better controlled.
\end{abstract}

Keywords: pollution, burning particles, micronuclei, Tradescantia pallida .

Partículas derivadas da queima de biomassa induzem alta frequência de micronúcleos no ensaio de Tradescantia pallida (TRAD-MN)

\section{Resumo}

A coleta de cana-de-açúcar manual é geralmente realizada após a queima, a qual é responsável pela emissão sazonal de poluentes atmosféricos no Brasil e acredita-se que este seja responsável pelos efeitos deletérios a saúde da população exposta. O potencial mutagênico da queima de cana-de-açúcar e partículas oriundas de resíduos em cinza de óleo queimado (ROFA) foi avaliado em ensaio que mede a freqüência de micronúcleos $(\mathrm{MN})$ em células mãe de grão de pólen de Tradescantia pallida (TRAD-MN). A freqüência de TRAD-MN em resíduos de queima de cana de açúcar (SCBR) nas doses de 0.3 e $0,03 \mathrm{mg} / \mathrm{mL}$ foi, respectivamente de $2,18 \pm 0,35$ e 5,53 $\pm 1,04$, enquanto para ROFA de incinerador e ROFA de um precipitador eletrostático instalado em uma chaminé de uma indústria siderúrgica, a freqüência de $\mathrm{MN}$ foi, respectivamente, $3,43 \pm 0,7$ e 4,90 $\pm 1,07$. Diferença significante foi observada entre os grupos $(\mathrm{p}<0,001)$, demonstrando que SCBR foi ao menos tão genotóxico quanto às partículas derivadas de combustíveis fósseis. Os resultados sugerem que o processo de queima de cana-de-açúcar no período da safra deveria ser mais bem controlado.

Palavras-Chave: poluição, partículas de queimadas, micronúcleos, Tradescantia pallida.

*Corresponding author: Christiane Pienna Soares, e-mail: soarescp@hotmail.com 


\section{INTRODUCTION}

Biomass is a major source of domestic energy for half of the world's population; $90 \%$ of the rural regions in developing countries utilize energy derived from wood, coal, animal excrement, and agricultural residues (WHO, 2000). Biomass is still commonly employed for agricultural purposes in developing countries. Even in organized rural settings, such as is the case with sugar cane production in Brazil, burning is commonly used. Brazil is the largest world alcohol producer and exporter, considered as clean fuel, because it originates from sustainable sources. Nowadays the cultivated area comprehends 7 million hectares and the Brazilian production of sugarcane for the 2008/2009 harvest will reach 571,4 million tons (CONAB, 2008). In this scenario $70 \%$ of the country's sugar cane is burnt to make the process of manual harvesting easier, by protecting the rural workers from the sharp leaves, insects and poisonous snakes, and also to increase the sugar content by weight due to water evaporation (Zamperlini et al., 2000). Since the burning of sugar cane does not result in high temperatures, there is incomplete combustion of the biomass, which results in the generation of several organic compounds, including polycyclic aromatic hydrocarbons and aldehydes (Chen \& Chiu, 2003). These compounds are believed to be responsible for deleterious health effects in exposed populations (Arbex et al., 2000; Buschini et al., 2001). Zamperlini et al. (2000) detected polycyclic aromatic hydrocarbons in sugar cane burning residues (SCBR) which show genotoxic activity. Studies demonstrated that particulate matter (PM) obtained during sugar cane harvesting season demonstrated mutagenic potential and can induce significant alterations in pulmonary mechanics and lung histology in mice (Mazzolli-Rocha et al., 2008, Umbuzeiro et al., 2008). This being the case, studies evaluating the mutagenic potential of SCBRs is necessary to help assess the risk of exposed populations. Although indoor biomass burning has been associated with the development of lung cancer (Smith \& Liu, 1993) and laryngeal cancer (Clifford, 1972), little is known about the effects of outdoor biomass burning, probably because the ambient levels of such pollution depend upon the generation of sporadic fires, a requirement that is not conducive to conducting large-scale population studies over extended periods of time. Indeed, most of the knowledge about the cancer risk and mutagenic potential of ambient particle pollution comes from studies on fossil fuel derived emissions (Bernstein et al., 2004; Buschini et al., 2001). Considering that petroleum reserves will become scarce and ethanol could be an alternative fuel, we anticipate that burning sugar cane biomass could become a world problem in the future.

The induction of micronuclei (MN) in dividing cells is used as a biomarker to characterize the mutagenic potential of complex substances. MN are cytoplasmic chromatincontaining bodies that are formed when acentric chromosome fragments or whole chromosomes lag during anaphase and fail to become incorporated into daughter cell nuclei during cell division (Heddle, 1973; Schmidt, 1975; Von Ledebur \& Schmidt, 1973). Thus, the genetic damage that results in chromosome breaks, structurally abnormal chromosomes, and spindle abnormalities leads to $\mathrm{MN}$ formation and the incidence of $\mathrm{MN}$ in plant cells could serve as biomarker of mutagenicity caused by air pollutants (Medeiros et al., 2004; Carvalho-Oliveira et al., 2005). Tradescantia pallida potentially can accumulate DNA damage via in situ exposure, which could be useful for air pollution biomonitoring and outdoor pollution control (Sumita et al., 2003). Micronuclei in pollen mother cells of Tradescantia pallida (TRAD-MN) have been proposed as a useful tool in order to characterize the mutagenic potential of complex matrices (Ma et al., 1994). Although the measurement of MN in blood cells of mice is commonly used for hazard identification, the evaluation of TRAD-MN has been described as an efficient and inexpensive bioassay for monitoring the mutagenic effects of air pollutants (Carvalho-Oliveira et al., 2005).

In the present study, we analyzed the elemental composition of SCBR, and we evaluated the mutagenicity of sugar cane harvesting particulate in plants by measuring TRAD-MN. In addition, the mutagenicity of harvesting particulate was compared with the mutagenicity of particles derived from industrial processes powered by fossil fuels.

\section{MATERIALS AND METHODS}

\section{Test particles}

The SCBR were collected over a period of 24 h by dry deposition in several plastic receptacles with an area of 177 $\mathrm{cm}^{2}$ and filled with $1.5 \mathrm{~L}$ of water. The receptacles were placed close to where sugar cane burning was occurring, as described by Arbex et al., (2000). The openings of the receptacles were protected to avoid contamination by leaves and large insects. The contents of the receptacles were centrifuged at $256 \mathrm{x} \mathrm{g}$ for $10 \mathrm{~min}$, dried at $37^{\circ} \mathrm{C}$ and the pellet was stored at room temperature.

Two samples of particles representative of fossil fuel burning were assayed for comparison. The particles were generated by the combustion of different types of residual oil fly ash (ROFA). One of them was collected from the solid waste incinerator of the University Hospital of the University of São Paulo (ROFA/UH), which is powered by combustibles; the other was collected by an electrostatic precipitator installed in one of the chimneys of a large steel plant in Brazil (ROFA/EP).

\section{Characterization of particles}

Suspensions of test particles were produced by ultrasonication in saline, at concentrations of 0.03 and $0.3 \mathrm{mg} /$ $\mathrm{ml}$ for the SCBR, and at $0.3 \mathrm{mg} / \mathrm{ml}$ for the ROFA/UH and ROFA/EP. We decided utilized the high concentration of ROFA 
because possess DNA damage whereas 0.03 does not induces this damage. The elemental composition of the SCBR samples was determined by neutron activation analysis. The evaluation of the ROFA/UH and ROFA/EP samples was previously reported by Medeiros et al. (2004). Basically, the procedure involved short irradiations of $1 \mathrm{~min}$ for the determination of $\mathrm{Cl}, \mathrm{K}, \mathrm{Mg}, \mathrm{Mn}, \mathrm{Na}, \mathrm{Ti}$, and $\mathrm{V}$, using a pneumatic transfer system under a thermal neutron flux of $1.4 \times 10^{12} \mathrm{n} \mathrm{cm}^{-2} \mathrm{~s}^{-1}$. Longer irradiations of $16 \mathrm{hr}$ under a thermal neutron flux of about $10^{12} \mathrm{n} \mathrm{cm}^{-2} \mathrm{~s}^{-1}$ were performed for determinations of As, $\mathrm{Ba}, \mathrm{Br}, \mathrm{Ca}, \mathrm{Ce}, \mathrm{Co}, \mathrm{Cr}, \mathrm{Cs}, \mathrm{Fe}, \mathrm{Hf}, \mathrm{K}, \mathrm{La}, \mathrm{Mn}, \mathrm{Mo}, \mathrm{Na}, \mathrm{Nd}$, $\mathrm{Rb}, \mathrm{Sb}, \mathrm{Sc}, \mathrm{Se}, \mathrm{Sm}, \mathrm{Th}, \mathrm{U}, \mathrm{V}$, and Zn. After appropriate decay times, the irradiated samples and standards were measured using a hyperpure Ge detector Model GX2020 coupled to Model 1510 integrated signal processor (both from Canberra, Australia). Counting times from 200 to $50,000 \mathrm{sec}$ were used, depending on the half-lives or activities of the radioisotopes measured in three independent assays. The radioisotopes were identified according to their half-lives and $\gamma$-ray energies (Table I). The concentrations of the elements were calculated using a comparative method (Saiki et al., 1997).

\section{Exposure protocol}

The TRAD-MN assay was performed in early tetrads of Tradescantia pallida (Ma, 1979; Carvalho-Oliveira et al., 2005). The assay contained groups with 15 plants, each having a single inflorescence and the groups were: (1) positive control (formaldeyide $1000 \mathrm{ppm}$ ), (2) a negative control (Hoagland solution), and for each test group, the inflorescences were treated with sugar cane harvesting particulate, ROFA/EP or ROFA/UH. The plants were obtained from the School of Medicine's gardens and kept in the laboratory for $24 \mathrm{~h}$ in Hoagland's solution before treatment. After this period, cuttings were transferred to beakers and maintained for 8 $\mathrm{h}$ at room temperature according purposed by Ma (1979). After the treatment, the plants were allowed to recover for $24 \mathrm{hr}$ in Hoagland's solution. At the end of recovery time, inflorescences were fixed in ethanol-acetic acid (3:1 ratio, freshly prepared) for 48 hours and then transferred into $70 \%$ ethanol for storage in refrigerator for 2 weeks.

\section{Micronucleus assay}

The fifteen inflorescences were placed in separated flask and their identification were coded in order to evaluated the MN frequency in blind protocol. The code was revealed only after the completion of the experiment. The selection of appropriated bud in the early tetrad stage was performed from a series of buds of an inflorescence and the anthers were further macerated with a small drop of acetocarmine stain. The wall cells and debris were removed from surface of the slide and a cover glass was placed gently. The slides were submitted to heating temperature around $80^{\circ} \mathrm{C}$ on a low-heat alcohol lamp. The inflorescences, from control and test groups, were dissected and young anthers squashed in a solution of acetocarmine stain on a glass slide as described by Ma (1981).
Only preparations containing early tetrads were considered and the number of $\mathrm{MN}$ in 300 tetrads from each of the fifteen plants from each group was counted at 400x magnification. The results were expressed as the percent of tetrads containing $\mathrm{MN}$ (frequency of MN). A high homogeneity of tetrads in both control and test group as observed.

\section{Statistical analysis}

Data analysis was performed by repeated measures OneWay ANOVA, using either the mean frequency of MN in assay (mean of data from 15 plants), or the square root of the mean, as the dependent variable in the models. The StudentNewman-Keuls test was employed for post-hoc analysis. The level of significance was set at 5\%. Statistical analysis was conducted with the aid of SPSS v10.0 statistical software (SPSS, Chicago, IL).

\section{RESULTS}

Results obtained in analysis of the SCBR, ROFA/UH, and ROFA/EP samples demonstrated differences between the elemental compositions of the different combustion particle samples (Table 1). The SCBR sample had 10- to 100-times higher concentrations of $\mathrm{As}, \mathrm{Co}, \mathrm{Cs}, \mathrm{Mn}, \mathrm{Ti}$, and $\mathrm{V}$ than were found in ROFA/UH or ROFA/EP. In contrast, ROFA/EP had 5- to 50-times higher $\mathrm{Br}, \mathrm{Cr}, \mathrm{Fe}, \mathrm{Rb}$ and $\mathrm{Zn}$ then, respectively, SCBR or ROFA/UH. Otherwise, the highest concentrations of lanthanide elements were found in ROFA/UH, followed by ROFA/EP and then SCBR.

The elemental concentrations obtained from the analysis of the SCBR, ROFA/UH, and ROFA/EP samples and the detection limit values obtained according to the criteria Currie (1968). The data for ROFA/UH and ROFA/EP were previously reported (Medeiros et al., 2004) and are shown in the table for comparison with the elemental composition of SCBR. Neutron activation analysis was appropriate for characterizing this type of matrix due to its ability to analyze several elements using small samples, the quality of the results, and the low detection limits. The precision of the results determined for the SCBR is illustrated by standard deviations of less than $10 \%$ for most of elements. The accuracy of the analysis also was evaluated by analyzing NIST 1633b Coal Fly Ash and IAEA Soil-7 standards. The results that were obtained agreed with certified values (data not presented).

Results of the micronucleus assay are summarized in Table 2. The results indicated that gasoline engine exhaust significantly increased the formation of micronucleated cells at all the doses used in the experiments. In other hand, was not observed a dose-response relationship in SCBR samples. Significant differences were detected among the groups $(\mathrm{p}<$ 0.001). Student-Newman-Keuls post hoc analysis identified 3 groups, with some overlap among them: saline and $0.3 \mathrm{mg} / \mathrm{ml}$ SCBR; $0.3 \mathrm{mg} / \mathrm{ml} \mathrm{SCBR}$ and ROFA $/ \mathrm{UH}$; and, finally, $0.03 \mathrm{mg} /$ $\mathrm{ml}$ SCBR and both types of ROFA. For the negative control only a low rate of micronucleus was identified as $0,14 \%$. 
Table 1 - Chemical element concentrations in combustion particle samples determined by neutron activation analysis. $(\mathrm{Fe}, \mathrm{Ca}, \mathrm{Cl}, \mathrm{K}$ and $\mathrm{Mg}$ concentrations are given as percentages).

\begin{tabular}{|c|c|c|c|c|}
\hline \multirow{3}{*}{ Elements } & \multicolumn{3}{|c|}{ Samples } & \multirow{3}{*}{$\begin{array}{c}\text { Detection Limit } \\
\text { Values }\end{array}$} \\
\hline & \multirow{2}{*}{$\begin{array}{c}\operatorname{SCBR}(\mathrm{n}=3) \\
\operatorname{Mean} \pm \operatorname{SE}\end{array}$} & \multirow{2}{*}{$\begin{array}{c}\text { ROFA/UH }(\mathrm{n}=3)^{*} \\
\text { Mean } \pm \text { SE }\end{array}$} & \multirow{2}{*}{$\begin{array}{c}\text { ROFA/EP }(n=3) * \\
\text { Mean } \pm \text { SE }\end{array}$} & \\
\hline & & & & \\
\hline As, $\mu \mathrm{g} \mathrm{kg}^{-1}$ & $601 \pm 27$ & $9.3 \pm 1.0$ & $61.0 \pm 1.0$ & 5.2 \\
\hline $\mathrm{Br}, \mu \mathrm{g} \mathrm{g}^{-1}$ & $6.6 \pm 0.7$ & $8.7 \pm 0.6$ & $1482 \pm 19$ & 0.020 \\
\hline $\mathrm{Ca}(\%)$ & $6.9 \pm 0.3$ & $0.59 \pm 0.04$ & $5.4 \pm 0.2$ & 0.077 \\
\hline $\mathrm{Cl},(\%)$ & $0.34 \pm 0.05$ & ND & ND & 0.005 \\
\hline $\mathrm{Co}, \mu \mathrm{g} \mathrm{kg}^{-1}$ & $2039 \pm 196$ & $122.9 \pm 3.1$ & $9.96 \pm 0.25$ & 2.1 \\
\hline $\mathrm{Cr}, \mu \mathrm{g} \mathrm{g}^{-1}$ & $8.1 \pm 0.5$ & $32.4 \pm 0.4$ & $107.7 \pm 1.4$ & 0.014 \\
\hline $\mathrm{Cs}, \mu \mathrm{g} \mathrm{kg}^{-1}$ & $846 \pm 24$ & $0.58 \pm 0.04$ & $9.96 \pm 0.25$ & 0.28 \\
\hline $\mathrm{Fe}(\%)$ & $8.7 \pm 0.6$ & $3.28 \pm 0.07$ & $44.6 \pm 0.1$ & 0.0016 \\
\hline $\mathrm{K}(\%)$ & $5.6 \pm 0.1$ & ND & ND & 0.04 \\
\hline $\mathrm{La}, \mu \mathrm{g} \mathrm{g}^{-1}$ & $33 \pm 1$ & $972 \pm 12$ & $10.3 \pm 0.1$ & 0.04 \\
\hline $\mathrm{Mg},(\%)$ & $2,2 \pm 0.2$ & ND & ND & 0.12 \\
\hline $\mathrm{Mn}, \mu \mathrm{g} \mathrm{g}^{-1}$ & $1728 \pm 123$ & ND & ND & 0.7 \\
\hline Mo, $\mu \mathrm{g} \mathrm{g}^{-1}$ & $2.6 \pm 0.4$ & ND & ND & 1.5 \\
\hline $\mathrm{Na}, \mu \mathrm{g} \mathrm{g}^{-1}$ & $365 \pm 46$ & NA & NA & 0.10 \\
\hline $\mathrm{Rb}, \mu \mathrm{g} \mathrm{g}^{-1}$ & $57 \pm 1$ & $11.4 \pm 1.1$ & $719.7 \pm 1.0$ & 2.7 \\
\hline $\mathrm{Sb}, \mu \mathrm{g} \mathrm{kg}^{-1}$ & $305 \pm 112$ & $39.8 \pm 0.7$ & $2.27 \pm 0.09$ & 1.0 \\
\hline $\mathrm{Sc}, \mu \mathrm{g} \mathrm{kg}^{-1}$ & $2487 \pm 192$ & $1.111 \pm 0.007$ & $1.91 \pm 0.01$ & 0.33 \\
\hline Se, $\mu \mathrm{g} \mathrm{kg}^{-1}$ & $540 \pm 65$ & $20.5 \pm 0.2$ & $154.4 \pm 0.8$ & 15.7 \\
\hline $\mathrm{Ti}, \mu \mathrm{g} \mathrm{g}^{-1}$ & $2144 \pm 6$ & ND & ND & 50 \\
\hline $\mathrm{V}, \mu \mathrm{g} \mathrm{g}^{-1}$ & $29 \pm 3$ & ND & ND & 14 \\
\hline $\mathrm{Zn}, \mu \mathrm{g} \mathrm{g}^{-1}$ & $101 \pm 5$ & $115.7 \pm 1.5$ & $491.9 \pm 3.1$ & 3.1 \\
\hline $\mathrm{Hf}, \mu \mathrm{g} \mathrm{g}^{-1}$ & NA & $1.64 \pm 0.03$ & $0.62 \pm 0.07$ & 0.10 \\
\hline $\mathrm{Th}, \mu \mathrm{g} \mathrm{g}^{-1}$ & NA & $3.07 \pm 0.03$ & $1.50 \pm 0.06$ & 0.09 \\
\hline $\mathrm{U}, \mu \mathrm{g} \mathrm{g}^{-1}$ & NA & ND & $2.28 \pm 0.14$ & 0.30 \\
\hline $\mathrm{Ce}, \mu \mathrm{g} \mathrm{g}^{-1}$ & NA & $51.1 \pm 0.4$ & $16.3 \pm 0.3$ & 0.35 \\
\hline $\mathrm{Nd}, \mu \mathrm{g} \mathrm{g}^{-1}$ & NA & $33.1 \pm .2 .9$ & $9.3 \pm 1.6$ & 4.5 \\
\hline $\mathrm{Sm}, \mu \mathrm{g} \mathrm{g}^{-1}$ & NA & $2.69 \pm 0.08$ & $2.30 \pm 0.07$ & 0.008 \\
\hline
\end{tabular}

SCBR (sugar cane burning residues), ROFA/UH (residual oil fly ash from University Hospital of the University of São Paulo), and ROFA/EP (residual oil fly ash collected from an electrostatic precipitator). ND =Not detected under analysis conditions. NA = not analyzed. Number $\mathrm{n}$ indicates number of determinations and in the case of $\mathrm{n}=1$ the uncertainty of the result was evaluated considering statistical counting errors of standard and sample. * Medeiros et al., 2004.

Table 2 - Micronucleus frequencies (expressed as percent micronucleated tetrads) measured in 300 pollen mother cells from ten to fifteen Tradescantia pallida inflorescences exposed to combustion particles.

\begin{tabular}{lccc}
\hline \hline Group & Mean $\left.*^{*}\right)$ & Standard Error (SE) & $\mathrm{N}$ \\
\hline Negative Control & 0.14 & 0.06 & 13 \\
Positive Control & 4.70 & 1.05 & 10 \\
SCBR 0.3 & 2.18 & 0.35 & 13 \\
SCBR 0.03 & 5.53 & 1.04 & 15 \\
ROFA EP & 4.90 & 1.07 & 10 \\
ROFA UH & 3.43 & 0.70 & 11 \\
\hline \hline
\end{tabular}

SCBR (sugar cane burning residues), ROFA/UH (residual oil fly ash from University Hospital incinerator of the University of São Paulo), and ROFA/EP (residual oil fly ash collected from an electrostatic precipitator Brazilian siderurgical company). Positive control (formaldehyde 1000 ppm), Negative control (Hoagland). $\mathrm{N}=$ Number of the plants treated with one inflorescence. Significant effects of time ( $<0.001) .(*)$ Mean MN in 300 tetrads from each of at least 15 plants/group (one inflorescence/plant).

\section{DISCUSSION}

The present study compared the genotoxicity of SCBR with particles produced by fossil fuel combustion that have previously been evaluated for chemical composition and toxicity (Medeiros et al., 2004).
The results indicated that the genotoxicity of SCBR is similar to that of the ROFA samples. Interestingly, no clear dose-responses were observed for the SCBR; it rather behaved in a positive-negative pattern. The reason for such behavior is not easy to determine, since both test agents - ROFA and SCBR - are composed of several chemical species, making it almost 
impossible to draw conclusions about which components are responsible for the observed effects and what are their individual dose-response profiles. However, raw SCBR particles that were subjected to minimal extraction procedures were genotoxic in plants, indicating that the test particles maybe represent a possible cancer risk in populations having continuous exposure to them. At the moment, no studies were performed with SCBR and other plants. However, some studies have been performed assessing the genotoxicity of anothers urban air pollutants (Carvalho-Oliveira et al., 2005; Meireles et al., 2009; Villarini et al., 2009).

In the present study, we observed high homogeneity of tetrads in both control and test group. Despite of the great variability observed in TRAD-MN frequency among the inflorescences in the same group, we were able to verify a reproducible doseresponse effect through of $\mathrm{MN}$ in plants. Oxidative damage induction by the PM also may have contributed to genotoxicity induced by SCBR. The oxidative stress mediated by PM may arise from direct generation of reactive oxygen species from the surface of particles, soluble compounds such as transition metals or organic compounds, altered function of mitochondria or NADPH-oxidase, and activation of inflammatory cells capable of generating reactive oxygen species and reactive nitrogen species (Risom et al., 2005).

In the present study, higher genotoxicity responses were observed for the lower concentration of SCBR $\left(0.03 \mathrm{mg} \mathrm{ml}^{-1}\right)$ than the higher concentration in the TRAD-MN assay. Since the chromosomal damage being detected itself is a cause of cellular death, it is expected that significant levels of aberrations and MN only will be found at toxic or near-toxic levels (Heddle, 1973). We hypothesize that lower concentrations of biomass suspensions might contain more aggregates of particles, resulting in higher frequency of micronuclei. The ultrafine fraction can favor the adsorption in the cells of mutagenic and carcinogenic species, such as PAHs, nitroaromatic hydrocarbons and metals (Claxton et al., 2004). In lower particles generally contains high amounts of transition metal ions ( $\mathrm{Fe}, \mathrm{Cu}, \mathrm{Zn}$, etc.,) recognized as potent inducers of oxidative DNA damage (Knaapen et al., 2002; Bonetta et al., 2009).

Although MN mice assay is pretty standard for hazard analysis, the TRAD-MN assay has been considered a quick, simple and efficient method to evaluate clastogenic or mutagenic effects of many compounds including natural products The TRAD-MN assay has been considered a quick, simple and efficient method to evaluate clastogenic or mutagenic effects of many compounds including natural products (Zhang et al., 1999). TRAD-MN have been used to evaluate mutagenic activity of air pollutants (Carvalho-Oliveira et al., 2005), wastewater (Ma, 1992), drinking water (Monarca et al., 2005) and ; radiation (Minouflet et al., 2005). Actually, the MN test has been used to screen mutagenic effects of substances. Genetic changes at both the gene and chromosomal level can be detected in plants without the complicated laboratory facilities required for many other assays. However, differences between plants and animals (e.g., in cell walls, metabolism, routes of exposure) make the extrapolation of data from plants to human difficult and, at times, of uncertain value. However, much of fundamental knowledge about modern genetics and the toxicology was first established in higher plants (Claxton \& Woodall, 2007). Moreover, the evaluation of $\mathrm{MN}$ in Tradescantia pallida has been described as more efficient test, in comparison with Tradescantia stamen hair mutation and Allium root anaphase aberration (Cabrera \& Rodriguez, 1999) and it could be considered an inexpensive bioassay for monitoring mutagenic effects.

Tradescantia clone 4430 is elegible to determine mutagenicity and its principal advantage is the absence of mutagenic changes, genetic homogeneity from plant to plant and experiment to experiment (Ma et al., 1994). Previous study has shown that TRAD-MN evaluation between Tradescantia pallida and Tradescantia clone 4430 were equally sensitive to $\mathrm{X}$-Ray. treatment, turning T. pallida TRAD-MN assay more feasible to tropical weather (Suyama et al., 2002).

The elemental composition of the SCBR sample indicated relatively high levels of $\mathrm{Ti}, \mathrm{Mn}$, and $\mathrm{V}$, which might have contributed to the TRAD-MN measured in the assays. In contrast, ROFA/UH and ROFA/EP had undetectable concentrations of these elements. Previous studies demonstrated significant differences in trace elements in urban pollution from regions with heavier dieselpowered truck traffic in comparison with samples from clean regions (Sumita et al., 2003). Thus, the evaluation of trace elements seems to be useful for characterizing which elements contribute to genotoxicity. It is possible that the metals present in SCBR might be able to induce high levels of DNA breakage, which could be involved in carcinogenic or mutagenic processes. Compounds containing Ti, Mn, and $\mathrm{V}$ were associated with genoxicicity and carcinogenicity (Katzer et al., 2003; Moroshita et al., 2004). High levels of metal-containing PM are believed to promote carcinogenesis because of their ability to cause oxidative DNA injury (Kim et al., 2003). In addition, coal combustion contributes to the dispersion of $\mathrm{V}, \mathrm{S}$, and $\mathrm{Se}$, and coal combustion is associated with high mortality in exposed individuals (Grahame \& Hidy, 2004).

In summary, the results of the present study indicate that SCBRs are at least as genotoxic as the fossil fuel derived particles assayed. Thus, the burning to harvest sugar cane should be avoided or at least better controlled.

Acknowledgments: The authors are thankful to CNPq and FAPESP for financial support. Funding Sources: Laboratory of Clinical Cytology and Cellular Biology, Department of Clinical Analysis, School of Pharmaceutical Sciences, University of São Paulo State (UNESP). Laboratory of Experimental Air pollution, Faculty of Medicine, Department of Pathology, School of Medicine, University of São Paulo (USP). CNPq and FAPESP, a Brazilian Foundations Research.

\section{Funding Sources:}

Laboratory of Clinical Cytology and Cellular Biology, Department of Clinical Analysis, School of Pharmaceutical Sciences, University of São Paulo State (UNESP).

CNPq and FAPESP, a Brazilian Foundations Research. 


\section{REFERENCES}

ARBEX, M.A., BOHM, G.M., SALDIVA, P.H.N., CONCEIÇÃO, G.M.S., POPE III, A.C. \& BRAGA, A.L.F., 2000, Assessment of the effects of sugar cane plantation burning on daily counts of inhalation therapy. J Air \& Waste Manage Assoc., 50:17451749.

BERNSTEIN, J.A., ALEXIS, N., BARNES, C., BERNSTEIN, L., NEL, A., PEDEN, D., DIAZ-SANCHES, D., TARLO, S.M. \& WILLIAMS, P.B., 2004, Health effects of air pollution. $J$. Allergy Clin. Immunol., 114:1116-1123.

BONETTA, S., GIANOTTI, V., SI. BONETTA, S., GOSETTI,F., ODDONE, M., GENNARO,M.C. \& CARRARO, E., 2009, DNA damage in A549 cells exposed to different extracts of $\mathrm{PM}_{2.5}$ from industrial, urban and highway sites. Chemosphere. doi:10.1016/j. chemosphere.2009.07.076.

BUSCHINI, A., CASSONI, F., ANCESCHI, E., PASINI, L., POLI, P. \& ROSSI, C., 2001, Urban airborne particulate: genotoxicity evaluation of different size fractions by mutagenesis test on microorganisms and comet assay. Chemosphere., 44:17231736.

CABRERA, G.L. \& RODRIGUEZ, D.M., 1999, Genotoxicity of soil from farmland irrigated with wastewater using three plant bioassays. Mutat.Res., 426(2):211-4. doi:10.1016/S00275107(99)00070-6.

CARVALHO-OLIVEIRA, R., POZO, R.M.K., LOBO, D.J.A., LICHTENFELS, A.J.F.C., MARTINS-JUNIOR, H. A., BUSTILHO, J.O.W.V., SAIKI, M., SATO, I.M. \& SALDIVA, P.H.N., 2005, Diesel emissions significantly influence composition and mutagenicity of ambient particles: a case study in São Paulo, Brazil. Environ. Res., 98:1-7. doi:10.1016/j. envres.2004.05.007.

CHEN, S.J. \& CHIU, S.C., 2003, Characteristics of the PAH emissions from the incineration of livestock wastes with/without APCD. Environ Int., 28:659-668. doi:10.1016/S0160-4120(02)00145-9.

CLAXTON, L.D., G.M. \& WOODALL JR. G.M., 2007, A review of the mutagenicity and rodent carcinogenicity of ambient air, Mutat. Res.: Rev. Mutat. Res. doi:10.1016/j.mrrev.2007.01.001.

CLAXTON, L.D., MATTHEWS, P.P. \& WARREN, S.H., 2004, The genotoxicity of ambient outdoor air, a review: Salmonella mutagenicity. Mutat. Res., 567:347-399. doi:10.1016/j. mrrev.2004.08.002.

CLIFFORD, P., 1972, Carcinogens in the nose and throat. Proceedings of the Royal Society of Medicine., 65:682-686.

CONAB - Companhia Nacional de Abastecimento. 2008, Ministério da Agricultura. Pecuária e Abastecimento. Acompanhamento da Safra Brasileira Cana-de-Açúcar Safra 2008. Terceiro levantamento.

CURRIE, L.A., 1968, Limits for quantitative detection and quantitative determination application to radiochemistry. Anal. Chem., 40: 586-593.doi: 10.1021/ac60259a007.

GRAHAME, T. \& HIDY, G., 2004, Using factor analysis to attribute health impacts to particulate pollution sources. Inhal. Toxicol., 16:143-152. doi: 10.1080/08958370490443231.

HEDDLE, J.A., 1973, A rapid in vivo test for chromosomal damage. Mutat. Res., 18:187-191. doi:10.1016/0027-5107(73)90035-3.

KATZER, A., BUCHHORN, G.H., HOCKERTZ, S. \& LOEHR, J.F., 2003, In vitro toxicity and mutagenicity of CoCrMo and TiAl wear particles. Toxicol., 190:145-154. doi: 10.1007/s00132003-0472-8.

KIM, J.Y., MUKHERJEE, S., NGO, L.C. \& CHRISTIANI, D.C., 2003, Urinary 8-hydroxy-2'-deoxyguanosine as a biomarker of oxidative DNA damage in workers exposed to fine particulates. Environ. Health. Perspect., 112:666-674. doi:10.1289/ehp.6827.

KNAAPEN, A.M., SHI, T., BORM, P.J.A. \& SCHINS, R.F.P., 2002,
Soluble metals as well as the insoluble particle fraction are involved in cellular DNA damage induced by particulate matter. Mol. Cell Biochem., 234/235:317-326. doi: 10.1023/A:1015970023889.

MA, T.H., 1979, Micronuclei induced by X-rays and chemical mutagens in meiotic pollen mother cells of Tradescantia. A promisingtestsystem. Mutat. Res.,64:307-313. doi:10.1016/01651161(79)90123-7.

MA, T.H., 1981, Tradescantia micronucleus bioassay and pollen tube aberration test for in situ monitoring and mutagen screening. Environ. Health Perspect., 37:85-90.

MA T.H, SANDHU, S.S., PENG, Y., CHEN, T.D. \& KIM, T.W., 1992, Synergistic and antagonistic effects on mutagenicity of chemicals commonly found in hazardous waste sites. Mut. Res., 270 (1): 71-77. doi:10.1016/0027-5107(92)90103-9.

MA, T.H., CABRERA, R., CHEN, R., GILL, B.S., SANDHU S.S, VANDERBERG, A.L. \& SALAMONE, M.F., 1994, Tradescantia micronucleus bioassay. Mut. Res., 310: 221-230. doi:10.1016/0027-5107(94)90115-5.

MAZZOLI-ROCHA, F., MAGALHÃES, C.B., MALM, O., SALDIVA, P.H.N., ZIN, W.A. \& FAFFE, D.S., 2008, Comparative respiratory toxicity of particles produced by traffic and sugar cane burning. Environ. Res. doi:10.1016/j. envres.2008.05.004.

MEDEIROS, N. J., RIVERO, D. H. R. F., KASAHARA, D. I., SAIKI, M., GODLESKI, J. J., KOUTRAKIS, P., CAPELOZZI, V. L., SALDIVA, P. H. N. \& ANTONANGELO, L., 2004, Acute pulmonary and hematological effects of two types of particle surrogates are influenced by their elemental composition. Environ. Res., 95: 62-70. doi:10.1016/j.envres.2003.07.007.

MEIRELES, J., ROCHA, R.; NETO, A.C. \& CERQUEIRA, E., 2009, Genotoxic effects of vehicle traffic pollution as evaluated by micronuclei test in Tradescantia (Trad-MCN). Mutat Res.,675: 46-50. doi:10.1016/j.mrgentox.2009.02.005.

MINOUFLET, M., AYRAULT, S., BADOT, P.M., COTELLE, S. \& FERARD, J.F., 2005, Assessment of the mutagenicity of 137Cs radiation using Vicia-micronucleus, Tradescantia-micronucleus and Tradescantia-stamen-hair mutation bioassays. Journal of Environmental Radioactivity., 81 (2-3): 143-153. doi:10.1016/j. jenvrad.2005.01.003.

MONARCA, S., FERETTI, D., ZANI, C., RIZZONI, M., CASARELLA, S. \& GUSTAVINO, B., 2005, Genotoxicity of drinking water disinfectants in plant bioassays. Environ. Mol. Mutagen., 46:96-103. doi:10.1002/em.20137.

MORISHITA, M., KEELER, G., WAGNER, J., MARSIK, F., TIMM, E., DVONCH, J. \& HARKEMA, J., 2004, Pulmonary retention of particulate matter is assossiated with airway inflammation in allergic rats exposed to air pollution in urban Detroit. Inhal Toxicology., 16:663-674. doi: 10.1080/08958370490476550.

RISOM, L., MOLLER, P. \& LOFT, S., 2005, Oxidative stressinduced DNA damage by particulate air pollution. Mut. Res., 592: 119-137. doi:10.1016/j.mrfmmm.2005.06.012.

SAIKI, M., VASCONCELLOS, M.B.A. \& MARCELLI, M.P., 1997, Determinations of trace elements in lichens by instrumental neutron activation analysis. J. Radioanal. Nucl. Chem., 217:111115 .

SCHMIDT, W., 1975, The micronucleus test. Mutat. Res., 31: 9-15.

SMITH, K.R. \& LIU, Y., 1993, Indoor air pollution in developing countries. In: Samet J, ed. Epidemiology of lung cancer. Lung biology in health and disease. New York, Marcel Dekker, 358359.

SUMITA, N.M., MENDES, M.E., MACCHIONE, M., GUIMARÃES, E.T., LICHTENFELS, A.J.F.C., LOBO, D.J.A. \& SALDIVA, P.H.N., 2003, Tradescantia pallida cv. purpurea boom in the characterization of air pollution by accumulation of trace elements. J Air \& Waste Manage Assoc., 53:574-579. 
SUYAMA, F., GUIMARÃES, E.T., LOBO, D.J.A., RODRIGUES, G.S, DOMINGOS, M., ALVES, E.S., CARVALHO, H.A. \& SALDIVA, P.H.N., 2002, Pollen mother cells of Tradescantia clone 4430 and Tradescantia pallida var. purpurea are equally sensitive to the clastogenic effects of X-rays. Braz. J. Med. Biol. Res., 35 (1): 127-129. doi: 10.1590/S0100879X2002000100018.

UMBUZEIRO, G.A., FRANCO, A.,MAGALHÃES, D., CASTRO, F.J.V., KUMMROW, F., RECH, C. M., CARVALHO, L. R. F. \& VASCONCELLOS, P.C., 2008, A Preliminary Characterization of the Mutagenicity of Atmospheric Particulate Matter Collected During Sugar Cane Harvesting Using the Salmonella/Microsome Microsuspension Assay. Environmental and Molecular Mutagenesis., 49: 249-255. doi: 10.1002/em.20378.

VILLARINI, M., FATIGONI, C., DOMINICI, L., MAESTRI, S., EDERLI, L., PASQUALINI, S., MONARCA, S. \& MORETTI, M., 2009, Assessing the genotoxicity of urban air pollutants using two in situ plant bioassays. Environ Pollut.,12: 3354-3356. doi:10.1016/j.envpol.2009.09.012.

VON LEDEBUR, M. \& SCHMIDT, W., 1973, The micronucleus test methodological aspects. Mutat. Res.,19: 109-137. doi:10.1016/0027-5107(73)90118-8.

ZAMPERLINI, G.C., SANTIAGO-SILVA, M. \& VILEGAS, W., 2000, Solid-phase extraction of sugar cane soot extract for analysis by gas chromatography with flame ionisation and mass spectrometric detection. J. Chromatogr. A., 889:281-286. doi:10.1016/S0021-9673(00)00291-0.

ZHANG, H., JEONG, B.S. \& MA, T.H., 1999, Antimutagenic property of an herbal medicine, Polygonum multiftorum Thunb. detected by the Tradescantia micronucleus assay. J. Environmental Pathology Toxicology Oncology., 18: 127-130.

WHO (WORLD HEALTH ORGANIZATION), 2000, Vegetation Fires, Fact Sheet, World Health Organ, 254. 